\title{
Associations between taste sensitivity, preference for sweet and salty flavours, and nutritional status of adolescents from public schools
}

\author{
Associação entre sensibilidade gustativa, \\ preferência aos sabores doce e \\ salgado e estado nutricional \\ de adolescentes
}

Marize Melo dos SANTOS1

Camila Santos MARREIROS 2

Herika Brenda Santana da SILVA ${ }^{3}$

Ana Raquel Soares de OLIVEIRA ${ }^{1}$

Kyria Jayanne Clímaco CRUZ ${ }^{1}$

\section{A B S TR A C T}

\section{Objective}

This study aimed to investigate the associations between taste sensitivity, preference for sweet and salty flavours, and nutritional status of adolescents in public schools.

\section{Methods}

We used a cross-sectional study involving 1,036 adolescents of both sexes, aged 10-19 years. Preference for sweet or salty flavours and preference for foods high in sugar or sodium were evaluated. Measurements of body mass index and taste flavour intensity recognition were conducted.

\section{Results}

Most participants were unable to identify the flavours and/or intensities, and only $18.0 \%$ of participants were able to correctly identify both the flavour and intensity of the samples. Most participants (82.1\%) preferring

\footnotetext{
1 Universidade Federal do Piaú, Centro de Ciências da Saúde, Programa de Pós-Graduação em Alimentos e Nutrição. Campus Universitário Ministro Petrônio Portela, Bloco 13, Ininga, 64049-550, Teresina, PI, Brasil. Correspondência para/ Correspondence to: MM SANTOS. E-mail: <marizesantos@ufpi.edu.br>.

2 Universidade Federal do Piaú, Centro de Ciências da Saúde, Departamento de Nutrição. Teresina, PI, Brasil.

3 Universidade Federal do Piauí, Centro de Ciências da Saúde, Departamento de Estatística. Teresina, PI, Brasil.
} 
sweet foods had low sensitivity to this taste, just as a large proportion of individuals preferring saltiness (82.3\%) were less sensitive to salt $(p<0.001)$. Preference for saltiness was associated with pre-obesity.

\section{Conclusion}

We found an association between a preference for sweet or salty flavours and nutritional status, highlighting the importance of poor food choices in the development of obesity and other chronic diseases.

Keywords: Adolescents. Nutritional status. Taste perception.

\section{R E S U M O}

\section{Objetivo}

Este estudo teve como objetivo investigar a associação entre a sensibilidade gustativa, a preferência pelos sabores doce e salgado e o estado nutricional de adolescentes em escolas públicas.

\section{Métodos}

Estudo de natureza transversal, envolvendo 1036 adolescentes de ambos os sexos, com idade entre 10 e 19 anos. A preferência pelos sabores doce e salgado e por alimentos ricos em açúcar ou sódio foi avaliada. Medidas do indice de massa corporal e testes de reconhecimento de gosto-intensidade foram conduzidos.

\section{Resultados}

A maioria dos participantes foi incapaz de identificar os sabores elou intensidades e somente 18,0\% dos participantes foram capazes de identificar corretamente o sabor e intensidade das amostras. A maioria dos participantes $(82,1 \%)$ preferiram alimentos doces e tiveram baixa sensibilidade a esse gosto, bem como uma grande proporção de indivíduos que preferem salgado (82,3\%) eram menos sensíveis ao sal $(p<0,001)$. A preferência pelo gosto salgado foi associada com excesso de peso.

\section{Conclusão}

Foi encontrada uma associação entre a preferência pelos sabores doce e salgado e o estado nutricional, destacando a importância de escolhas alimentares pobres no desenvolvimento de obesidade e outras doenças crônicas.

Palavras-chave: Adolescentes. Estado nutricional. Percepção gustatória.

\section{NTRODUCTION}

Human feeding behaviour can be influenced by several factors; psychological, social, economic, and sensory aspects play a decisive role in this behaviour. Among the sensory characteristics of the food, taste is the chief determinant of food choice [1]. Food preferences and aversions that are developed during childhood and adolescence are determined by the sensory characteristics of food [2] and are related to food choices throughout life $[3,4]$. In this sense, changes in taste sensitivity can influence preferences and dietary choices, contributing to changes in the nutritional status of adolescents [1]. Food preferences, in turn, seem to induce changes in taste sensation because excessive intake of sweet and savoury foods reduces sensitivity to these flavours [5].
Identification of taste sensitivity has been considered an important tool for understanding the complexity of adolescent food behaviour, and changes in taste sensation can contribute to forming unhealthy eating habits [1], promoting weight gain and obesity, as well as other chronic diseases in adulthood [6,7]. Obese individuals have differential taste sensitivity compared to eutrophic people. Overberg et al. [8] have shown that obese people are less able to identify flavours, particularly saltiness, umami, and bitterness. However, sensory education can promote the formation of healthy eating habits, since it encourages adolescents to taste different foods, and provides tools for making better food choices. These types of programs need to be integrated at the school, community, and family levels $[9,10]$. 
The objective of this study was to investigate the association between taste sensitivity, preference for sweet and salty flavours, and the nutritional status of adolescents from public schools in the city of Teresina, Piauí.

\section{METHODS}

This was a descriptive, cross-sectional study using a quantitative approach, which was carried out in public schools in the city of Teresina (PI), from February-May, 2015. The study included 1,036 adolescents of both sexes aged 10-19 who were present in the surveyed schools on the days when the questionnaires were applied. The study was approved by the Ethics Research Committee of the Federal Universidade Federal do Piauí, nº 406.353. Participants provided Informed Consent, including consent from parents and/or guardians according to the regulatory guidelines for research involving human beings, Resolution MS/CNS n 466/12 [11].

One-tenth of the city's municipal and state public schools were selected by random sampling, for a total of 20 schools located in five district areas of the city of Teresina (PI). Two classes from each school with students from the corresponding age group were randomly selected. All of the students in these classes who were present on the day of the survey were invited to participate. Absent students, students without the consent of their parents or guardians, and those who refused to participate, were excluded from the sample. The study also excluded smokers, adolescents with a disease or illness (e.g., fever, flu, sore throat, etc.), and anyone using drugs during the data collection period, since these conditions could interfere with flavour detection [12].

Survey questions included demographics and preferences to various sweet or salty foods. These included hamburgers, ham, soda, popcorn, pizza, stuffed cookies, cheese, lollipops, chewing gum, potato chips, chocolate milk, salty snacks, chocolate, crackers, chocolate cake, sausage, ice cream, instant noodles, hot dogs, mortadella, popsicles, and condensed milk. The food options also included the Brazilian dishes feijoada (a black bean and meat stew), bolo salgado (salty cake), and brigadeiro (chocolate truffles).

For the taste intensity recognition test, mineral water solutions were prepared with refined sugar concentrations of $2.0 \%$ and $4.0 \%$ for the sweet taste test, and table salt concentrations of $0.2 \%$ and $0.4 \%$ for the salty taste test. The flavours were presented at random, with the more concentrated samples offered first for both flavours [13]. The solutions were presented to participants, with each concentration presented in duplicate. Each participant was asked to identify the flavour and difference in intensity of the samples, and to order them in ascending or descending order according to the sensory attribute being assessed. Between tests, participants rinsed their mouths with water [13]. There was $100.0 \%$ accuracy in the identification of at least one of the two flavors. Participants who correctly identified the flavour and sample intensity were considered as 'approved', and those who were not able to correctly identify the taste, intensity or both were 'disapproved'.

Anthropometric measurements were taken in duplicate and presented as averages. Weight was measured using a portable digital balance (Techline TEC-130, São Paulo, Brazil) with a maximum capacity of $150 \mathrm{~kg}$ and $0.1 \mathrm{~kg}$ precision. Height was measured using a $2 \mathrm{~m}$ inelastic extension tape affixed vertically to the wall. Body mass index was calculated from the weight $(\mathrm{kg})$ of the participant divided by their height $(\mathrm{m})$ squared $\left(\mathrm{kg} / \mathrm{m}^{2}\right)$. Classifications were done using $\mathrm{BMl}$ percentiles for age and sex, according to the reference distribution of the World Health Organization [14].

Data were analysed using Statistical Package for the Social Sciences (SPSS Inc., Chicago, Illinois, United States) for Windows, v.20.0. Pearson's Chi-square $\left(\chi^{2}\right)$ tests and simple correspondence analyses were performed to assess the associations between variables. Significant associations were considered when $p<0.05$. 


\section{R E S U L T S}

The study included 1,036 adolescents of whom $53 \%$ were women. The average age of participants was 13 years, with $45 \%$ being $10-12$ years old, 30\% aged $13-15$, and $25 \%$ aged $16-19$.

In the taste intensity recognition test, there was a significant difference between those students both sexes who had successfully identified flavour intensity and those who did not. Most participants could not identify the flavours and/or intensities, and only $17.7 \%$ and $19.0 \%$ of male and female participants, respectively, were able correctly to identify both the flavour and intensity of the samples (Table 1).

Among the adolescents preferring sweet flavours, $82.1 \%$ were not sensitive to the sweet samples. Of the participants partial to salty flavours, $82.3 \%$ were not sensitive to the salty samples $(p<0.001$; Table 2).

We found a significant association between a preference for the analysed flavours and nutritional status, as well as pre-obese individuals with a preference for salty flavours (Table 3 ).

Correspondence analysis between flavour preferences and nutritional status of adolescents showed an association between normal weight and preference for sweet flavours with $70 \%$ confidence and between overweight and preference for salty flavours with $94 \%$ confidence.

We found a significant association between taste sensitivity to the salty samples and nutritional status ( $p=0.041)$. Most participants with thinness

Table 1. Distribution of adolescents from public schools in Teresina (PI), Brazil (2015), according to sensitivity to sweet and salty flavours and according to sex.

\begin{tabular}{|c|c|c|c|c|c|c|}
\hline \multirow{2}{*}{ Variable } & \multicolumn{3}{|c|}{ Male } & \multicolumn{3}{|c|}{ Female } \\
\hline & $\mathrm{n}$ & $\%^{+}$ & $p$ & $\mathrm{n}$ & $\%^{\dagger}$ & $p$ \\
\hline \multicolumn{7}{|l|}{ Taste and intensity test (sweet) } \\
\hline Approved & 111 & 28.1 & \multirow{2}{*}{$<0.001^{*}$} & 120 & 26.5 & \multirow{2}{*}{$<0.001$} \\
\hline Disapproved & 284 & 71.9 & & 332 & 73.5 & \\
\hline \multicolumn{7}{|l|}{ Taste and intensity test (salty) } \\
\hline Approved & 89 & 22.5 & \multirow{2}{*}{$<0.001^{*}$} & 128 & 28.3 & \multirow{2}{*}{$<0.001^{*}$} \\
\hline Disapproved & 306 & 77.5 & & 324 & 71.7 & \\
\hline \multicolumn{7}{|l|}{ Taste sensitivity } \\
\hline Taste correctly identified, intensity incorrectly identified & 171 & 35.7 & & 213 & 38.4 & \\
\hline Taste and intensity incorrectly identified & 223 & 46.6 & $<0.001^{*}$ & 236 & 42.6 & $<0.001^{*}$ \\
\hline Taste and intensity correctly identified & 85 & 17.7 & & 105 & 19.0 & \\
\hline
\end{tabular}

Note: ${ }^{\dagger}$ Percentage of total individuals by sex; ${ }^{P}$ Pearson's Chi-square test $\left(\chi^{2}\right)$.

Table 2. Association between taste sensitivity and food preference for sweet and salty flavours. Teresina (PI), Brazil (2015).

\begin{tabular}{|c|c|c|c|c|c|c|c|c|c|c|}
\hline \multirow{4}{*}{ Food preference } & \multicolumn{10}{|c|}{ Taste sensitivity } \\
\hline & \multicolumn{5}{|c|}{ Sweet } & \multicolumn{5}{|c|}{ Salty } \\
\hline & \multicolumn{2}{|c|}{ Approved } & \multicolumn{2}{|c|}{ Disapproved } & \multirow{2}{*}{$p^{*}$} & \multicolumn{2}{|c|}{ Approved } & \multicolumn{2}{|c|}{ Disapproved } & \multirow{2}{*}{$p^{*}$} \\
\hline & $n$ & $\%$ & $n$ & $\%$ & & $n$ & $\%$ & $n$ & $\%$ & \\
\hline Sweet & 81 & 17.9 & 371 & 82.1 & $<0.001$ & 147 & 32.5 & 305 & 67.5 & $<0.001$ \\
\hline Salty & 150 & 38.0 & 245 & 62.0 & & 70 & 17.7 & 325 & 82.3 & \\
\hline
\end{tabular}

Note: "Pearson's Chi-square test $\left(\chi^{2}\right)$. 
Table 3. Association between preference for sweet and salty flavours and nutritional status of adolescents from public schools in Teresina (PI), Brazil (2015).

\begin{tabular}{|c|c|c|c|c|c|}
\hline \multirow{3}{*}{ Nutritional status } & \multicolumn{4}{|c|}{ Flavour preference } & \multirow{3}{*}{$p^{*}$} \\
\hline & \multicolumn{2}{|c|}{ Sweet } & \multicolumn{2}{|c|}{ Salty } & \\
\hline & $n$ & $\%^{\dagger}$ & $n$ & $\%^{\dagger}$ & \\
\hline Thinness & 34 & 60.7 & 22 & 39.3 & \\
\hline Normal range & 411 & 55.4 & 331 & 44.6 & 807 \\
\hline Pre-obesity & 60 & 39.0 & 94 & 61.0 & 0.002 \\
\hline Obesity & 45 & 53.6 & 39 & 46.4 & \\
\hline
\end{tabular}

Note: ${ }^{\dagger}$ Percentage of total individuals in each nutritional status group; ${ }^{*}$ Pearson's Chi-square test $\left(\chi^{2}\right)$.

Table 4. Association between taste sensitivity and nutritional status of adolescents from public schools in Teresina (PI), Brazil (2015).

\begin{tabular}{|c|c|c|c|c|c|c|c|c|c|c|}
\hline \multirow{4}{*}{ Nutritional status } & \multicolumn{10}{|c|}{ Taste sensitivity } \\
\hline & \multicolumn{5}{|c|}{ Sweet } & \multicolumn{5}{|c|}{ Salty } \\
\hline & \multicolumn{2}{|c|}{ Approved } & \multicolumn{2}{|c|}{ Disapproved } & \multirow{2}{*}{$p^{*}$} & \multicolumn{2}{|c|}{ Approved } & \multicolumn{2}{|c|}{ Disapproved } & \multirow{2}{*}{$p^{*}$} \\
\hline & $n$ & $\%^{\dagger}$ & $n$ & $\%^{\dagger}$ & & $n$ & $\%^{\dagger}$ & $n$ & $\%^{\dagger}$ & \\
\hline Thinness & 17 & 37.0 & 29 & 63.0 & 0.263 & 6 & 13.0 & 40 & 87.0 & 0.041 \\
\hline Normal range & 156 & 25.6 & 454 & 74.4 & & 173 & 28.3 & 439 & 71.7 & \\
\hline Pre-obesity & 37 & 30.3 & 85 & 69.7 & & 26 & 21.3 & 96 & 78.7 & \\
\hline Obesity & 21 & 30.4 & 48 & 69.6 & & 14 & 20.3 & 55 & 79.7 & \\
\hline
\end{tabular}

Note: ${ }^{\dagger}$ Percentage of total individuals in each nutritional status group; ${ }^{*}$ Pearson's Chi-square test $\left(\chi^{2}\right)$.

(87.0\%), weight in normal range $(71.7 \%)$, pre-obesity (78.7\%) and obesity (79.7\%) were disapproved on taste sensitivity to the salty samples (Tabela 4).

There was a greater preference among participants for sweet flavours (53.10\%); however, with respect to food, most of the surveyed adolescents preferred brigadeiro, hamburgers, soda, popcorn, pizza, stuffed cookies, and hot dogs (Table 5).

\section{I SCUSS I O N}

This was the first study to associate taste sensitivity, preference for sweet and salty flavours, and the nutritional status of adolescents. High percentages of participants were insensitive to the two flavours, regardless of sex. High intake of foods with added sucrose and sodium may have contributed to the participants' difficulty in identifying the corresponding flavour's intensity, since excessive intake of these nutrients seems to favour reduction in taste sensitivity of adolescents [5]. From our study, adolescents preferred sweet flavours, which may be due to formation of dietary habits during breastfeeding and supplementary feeding, when a larger amount of sweet foods are offered. The literature shows that children and adolescents consume large amounts of sweet foods, consistent with our findings $[15,16]$.

This study has found that adolescents with sensitivity to sweetness prefer salty flavours, and those sensitive to saltiness prefer sweet flavours. This result confirms changes in taste sensitivity of these individuals, which can be attributed to inadequate feeding caused by frequent consumption of processed foods with high sugar, sodium, and fat content, and low consumption of natural foods. The surveyed students were not sensitive to their preferred flavours, suggesting 
Table 5. Foods liked or disliked by adolescents from public schools in Teresina (PI), Brazil (2015).

\begin{tabular}{|c|c|c|c|}
\hline \multirow{2}{*}{ Foods } & \multicolumn{3}{|c|}{ Preference or rejection } \\
\hline & $\mathrm{n}$ & $\%^{\dagger}$ & $p^{*}$ \\
\hline \multicolumn{4}{|c|}{ Brigadeiro } \\
\hline Like & 797 & 77.0 & \multirow{2}{*}{$<0.001$} \\
\hline Dislike & 238 & 23.0 & \\
\hline \multicolumn{4}{|c|}{ Hamburger } \\
\hline Like & 766 & 73.9 & \multirow{2}{*}{$<0.001$} \\
\hline Dislike & 270 & 26.1 & \\
\hline \multicolumn{4}{|l|}{ Ham } \\
\hline Like & 592 & 57.3 & \multirow{2}{*}{$<0.001$} \\
\hline Dislike & 441 & 42.7 & \\
\hline \multicolumn{4}{|l|}{ Soda } \\
\hline Like & 852 & 82.2 & \multirow{2}{*}{$<0.001$} \\
\hline Dislike & 184 & 17.8 & \\
\hline \multicolumn{4}{|c|}{ Popcorn } \\
\hline Like & 652 & 62.9 & \multirow{2}{*}{$<0.001$} \\
\hline Dislike & 384 & 37.1 & \\
\hline \multicolumn{4}{|l|}{ Pizza } \\
\hline Like & 916 & 88.4 & \multirow{2}{*}{$<0.001$} \\
\hline Dislike & 120 & 11.6 & \\
\hline \multicolumn{4}{|c|}{ Stuffed cookies } \\
\hline Like & 719 & 69.4 & \multirow{2}{*}{$<0.001$} \\
\hline Dislike & 317 & 30.6 & \\
\hline \multicolumn{4}{|c|}{ Hot dog } \\
\hline Like & 779 & 75.2 & \multirow{2}{*}{$<0.001$} \\
\hline Dislike & 257 & 24.8 & \\
\hline
\end{tabular}

Note: ${ }^{\dagger}$ Denotes percentage for each food type; ${ }^{*}$ Pearson's Chi-square test $\left(\chi^{2}\right)$.

that excessive exposure to a flavour seems to contribute to reduced sensitivity [5].

We found an association between food preference and nutritional status. Our correspondence analysis showed that normal-weight individuals preferred sweet flavours, while the overweight adolescents preferred salty flavours. The salty foods preferred by the evaluated teenagers, like hamburgers, pizza, and hot dogs, are sources of simple carbohydrates and saturated fats, which can contribute to obesity and associated diseases. Other studies have found that obese adults consume large amounts of foods with added salt, and that these foods contribute large proportions of the energy content in their diets. Researchers suggest that altered sensitivity to salty flavours can influence the feeding behaviour of obese individuals [17-19].

In this study, we also found an association between taste sensitivity to the salty samples and nutritional status. We observed that participants with thinness showed highest percentage of disapproval in this test. This result confirms previous results of this study because we found that most individuals with thinness preferred sweet flavours. Thus, this scientific evidence confirms the existence of changes in taste sensitivity of these individuals.

This study's limitations include a lack of data on food consumption that could explain the observed reduced taste sensitivity. More studies on the complex mechanisms involved in adolescents' taste sensitivity and food preferences are needed to further elucidate the influence of these factors on their food choices and nutritional status.

\section{CONCLUSION}

The adolescents evaluated in this study had low sensitivity to sweet and salty flavours. Adolescents with sensitivity to sweetness prefer salty flavours, and those sensitive to saltiness prefer sweet flavours, evidencing changes in taste sensitivity of these individuals. We found an association between a preference for sweet or salty flavours and nutritional status, and an association between sensitivity taste and nutritional status, highlighting the importance of poor food choices in the development of obesity and other chronic diseases.

\section{CONTRIBUTORS}

CS MARREIROS, HBS SILVA, ARS OLIVEIRA and KJC CRUZ have participated to the analysis and interpretation of data of the manuscript. MM SANTOS participated in the conception, design, development and the review of the paper. 


\section{R E FER E N CE S}

1. Estima CCP, Philippi ST, Alvarenga MS. Fatores determinantes de consumo alimentar: por que os indivíduos comem o que comem? Rev Bras Nutr Clin. 2009;24(1):263-8.

2. Sclafani A. Oral and postoral determinants of food reward. Physiol Behav. 2004;81(5):773-9. https:// doi.org/10.1016/j.physbeh.2004.04.031

3. Bellisle F. How and why should we study ingestive behaviors in humans? Food Qual Prefer. 2009;20(8):539-44. https://doi.org/10.1016/.ffoodqual. 2009.03.005

4. Mikkilä V, Räsänen L, Raitakari OT, Pietinen P, Viikari J. Longitudinal changes in diet from childhood into adulthood with respect to risk of cardiovascular diseases: The Cardiovascular risk in young Finns study. Eur J Clin Nutr. 2004;58(7):1038-45.

5. Guyton AC, Hall JE. Fundamentos de fisiologia. $12^{\mathrm{a}}$ ed. Amsterdã: Elsevier; 2011.

6. Conde WL, Borges C. O risco de incidência e persistência da obesidade entre adultos brasileiros segundo seu estado nutricional ao final da adolescência. Rev Bras Epidemiol. 2011;14(1):71-9. https://doi. org/10.1590/S1415-790X2011000500008

7. Levy RB, Castro IRR, Cardoso LO, Tavares LF, Vasconcelos LM, Gomes SFS, et al. Consumo e comportamento alimentar entre adolescentes brasileiros: Pesquisa Nacional de Saúde do Escolar (PENSE), 2009. Ciênc Saúde Coletiva. 2010;15(2):3085-97. https://doi. org/10.1590/S1413-81232010000800013

8. Overberg J, Hummel T, Krude $H$, Wiegand $S$. Differences in taste sensitivity between obese and non-obese children and adolescents. Arch Dis Child. 2012;97(12):1048-52. https://doi.org/10. 1136/archdischild-2012-302019

9. Costa AVS, Nicolau ES, Torres MCL, Fernandes $P R$, Rosa SIR, Nascimento RC. Desenvolvimento e caracterização físico-química, microbiológica e sensorial de bebida láctea fermentada elaborada com diferentes estabilizantes/espessantes. Sem Ciênc Agr. 2013;34(1):209-26. https://doi.org/10.5433/16 79-0359.2013v34n1p209

10. Atzingen MCBV, Silva MEMPE. Sensory characteristics of food as a determinant of food choices. J Bra Soc Food Nutr. 2010;35(3):183-96.
11. Ministério da Saúde (Brasil). Resolução no 466/12. Conselho Nacional de Pesquisa com Seres Humanos. Diário Oficial da União. 201213 jun [acesso 2016 fev 20]; (12):59; Seção 1. Disponível em: http://bvsms. saude.gov.br/ bvs/saudelegis/cns/2013/res046 6_12_ 12_2012.html

12. Kim UK, Jorgenson $E$, Coon $H$, Leppert $M$, Risch N, Drayna D. Positional cloning of the human quantitative trait locus underlying taste sensitivity to phenylthiocarbamide. Science. 2003;299(5610):1221-5. https://doi.org/10.1126/ science. 1080190

13. Dutcosky SD. Análise sensorial de alimentos. $2^{\mathrm{a}}$ ed. Curitiba: Champagnat; 2007.

14. Ministério da Saúde (Brasil). Protocolos do Sistema de Vigilância Alimentar e Nutricional - Sisvan na assistência à saúde. Brasília: Ministério da Saúde; 2008 [acesso 2016 jan 13]. Série B. Textos básicos de saúde. Disponível em: http://bvsms.saude.gov. br/bvs/publicacoes/protocolo_sistema_vigilancia_ alimnetar.pdf

15. Nicklaus S, Boggio V, Chabanet C, Issanchou S. A prospective study of food preferences in childhood. Food Qual Pref. 2004;15(7-8):805-18. https://doi.org/10.1016/j.foodqual.2004.02.010

16. Asao K, Luo W, Herman WH. 2014. Reproducibility of the measurement of sweet taste preferences. Appetite. 2012;59(3):927-32. https://doi.org/10.10 16/j.appet.2012.09.002

17. Cox DN, Perry L, Moore PB, Vallis L, Mela DJ. Sensory and hedonic associations with macronutrient and energy intakes of lean and obese consumers. Int J Obes Relat Metab Disord. 1999;23(4):403-10.

18. Donaldson LF, Bennett L, Baic S, Melichar JK. Taste and weight: Is there a link? Am J Clin Nutr. 2009;90(3):800S-3S. https://doi.org/10.3945/ajcn. 2009.27462Q

19. Keskitalo K, Tuorila H, Spector TD, Cherkas LF, Knaapila A, Kaprio J, et al. The Three-Factor Eating Questionnaire, body mass index, and responses to sweet and salty fatty foods: A twin study of genetic and environmental associations. Am J Clin Nutr. 2008;88(2):263-71.

Received: July 14, 2016

Final version: October 25, 2016

Approved: December 19, 2016 
